Rebecca L. Phillips · Donald R. Zak

William E. Holmes · David C. White

\title{
Microbial community composition and function beneath temperate trees exposed to elevated atmospheric carbon dioxide and ozone
}

Received: 1 August 2001 / Accepted: 13 December 2001 / Published online: 14 February 2002

(C) Springer-Verlag 2002

\begin{abstract}
We hypothesized that changes in plant growth resulting from atmospheric $\mathrm{CO}_{2}$ and $\mathrm{O}_{3}$ enrichment would alter the flow of $\mathrm{C}$ through soil food webs and that this effect would vary with tree species. To test this idea, we traced the course of $\mathrm{C}$ through the soil microbial community using soils from the free-air $\mathrm{CO}_{2}$ and $\mathrm{O}_{3}$ enrichment site in Rhinelander, Wisconsin. We added either ${ }^{13} \mathrm{C}$-labeled cellobiose or ${ }^{13} \mathrm{C}$-labeled $\mathrm{N}$-acetylglucosamine to soils collected beneath ecologically distinct temperate trees exposed for 3 years to factorial $\mathrm{CO}_{2}$ (ambient and $200 \mu \mathrm{l} \mathrm{l}^{-1}$ above ambient) and $\mathrm{O}_{3}$ (ambient and $20 \mu \mathrm{l}^{-1}$ above ambient) treatments. For both labeled substrates, recovery of ${ }^{13} \mathrm{C}$ in microbial respiration increased beneath plants grown under elevated $\mathrm{CO}_{2}$ by $29 \%$ compared to ambient; elevated $\mathrm{O}_{3}$ eliminated this effect. Production of ${ }^{13} \mathrm{C}-\mathrm{CO}_{2}$ from soils beneath aspen (Populus tremuloides Michx.) and aspen-birch (Betula papyrifera Marsh.) was greater than that beneath aspenmaple (Acer saccharum Marsh.). Phospholipid fatty acid analyses ( ${ }^{13} \mathrm{C}$-PLFAs) indicated that the microbial community beneath plants exposed to elevated $\mathrm{CO}_{2}$ metabolized more ${ }^{13} \mathrm{C}$-cellobiose, compared to the microbial community beneath plants exposed to the ambient condition. Recovery of ${ }^{13} \mathrm{C}$ in PLFAs was an order of magnitude greater for $\mathrm{N}$-acetylglucosamine-amended soil compared to cellobiose-amended soil, indicating that substrate type influenced microbial metabolism and soil $\mathrm{C}$ cycling. We found that elevated $\mathrm{CO}_{2}$ increased fungal
\end{abstract}

R.L. Phillips $(-)$ D.R. Zak · W.E. Holmes

School of Natural Resources and Environment,

University of Michigan, 430 E. University Avenue,

Ann Arbor, MI 48109-1115, USA

e-mail: rebecca@aero.und.edu

Tel.: +1-701-7776160

D.C. White

Center for Environmental Biotechnology, University of Tennessee, 10515 Research Drive, Knoxville, TN 37996, USA

Current address:

School of Aerospace, University of North Dakota,

University Avenue and Tulane Drive, Grand Forks,

ND 58202-9007, USA activity and microbial metabolism of cellobiose, and that microbial processes under early-successional aspen and birch species were more strongly affected by $\mathrm{CO}_{2}$ and $\mathrm{O}_{3}$ enrichment than those under late-successional maple.

Keywords Soil microorganisms .

Carbon-13-phospholipid fatty acid analysis .

Elevated carbon dioxide Elevated ozone .

Soil carbon cycling

\section{Introduction}

Human activity has increased the concentration of $\mathrm{CO}_{2}$ and $\mathrm{O}_{3}$ in the earth's troposphere (Barnola et al. 1995; Finlayson-Pitts and Pitts 1997), and each of these trace gases has the potential to modify photosynthesis and plant growth across broad geographic regions, albeit in opposing ways (Curtis 1996; Pye 1988). Understanding the response of forests to increasing concentrations of tropospheric $\mathrm{CO}_{2}$ and $\mathrm{O}_{3}$ is of particular importance, because these ecosystems contain a large proportion of the $\mathrm{C}$ stored on land (75\%) and account for $42 \%$ of global net primary productivity (Schlesinger 1997). Elevated $\mathrm{CO}_{2}$ often stimulates forest productivity, which is followed by greater soil $\mathrm{C}$ inputs through higher rates of litterfall, root turnover, and rhizodeposition (Pregitzer et al. 1995; DeLucia et al. 1999). In contrast, tropospheric $\mathrm{O}_{3}$ is a phytotoxic pollutant detrimental to forest productivity (Pye 1988; Karnosky et al. 1996). An increase in this trace gas has the potential to diminish greater forest growth and $\mathrm{C}$ storage resulting from elevated atmospheric $\mathrm{CO}_{2}$. However, it is not known how $\mathrm{CO}_{2}$ and $\mathrm{O}_{3}$ interact to influence the $\mathrm{C}$ cycle of forest ecosystems.

Plant growth, belowground $\mathrm{C}$ allocation, and microbial metabolism are inextricably linked to $\mathrm{C}$ cycling within an ecosystem (Zak et al. 1993). Microorganisms mediate soil $\mathrm{C}$ cycling and rely on substrate inputs from plant detritus as sources of energy for cellular metabolism. Greater belowground $\mathrm{C}$ inputs beneath plants growing under elevated $\mathrm{CO}_{2}$ are therefore expected to stimulate 
microbial metabolism of plant-derived substrates (Norby 1994; Pregitzer et al. 1995) and alter rates of $\mathrm{C}$ and $\mathrm{N}$ cycling in soil (Zak et al. 1993; Berntson and Bazzaz 1998). As elevated $\mathrm{CO}_{2}$ increases the flux of $\mathrm{C}$ from roots to soil (Van Veen et al. 1991; Canadell et al. 1996), there are a number of accompanying responses by soil microbial communities. These include greater turnover of soil bacteria and fungi (Hungate et al. 2000), enhanced bacterial utilization of substrates (Rillig et al. 1997), higher levels of microbial biomass (Williams et al. 2000), more rapid rates of respiration (Hungate et al. 2000; King et al. 2001) and increased extracellular enzyme activity (Dhillion et al. 1996; Larson et al., in press). Additionally, soil microbial communities may also be affected beneath trees exposed to elevated $\mathrm{O}_{3}$. Damage to the photosynthetic system in $\mathrm{O}_{3}$-sensitive plant species could reduce productivity and soil $\mathrm{C}$ inputs, thus counteracting the effects of elevated $\mathrm{CO}_{2}$ on microbial metabolism in soil.

We have been studying the influence of elevated $\mathrm{CO}_{2}$ and $\mathrm{O}_{3}$ on the growth of contrasting temperate tree species at the Rhinelander, Wisconsin, free-air $\mathrm{CO}_{2}-\mathrm{O}_{3}$ enrichment (FACE) site (King et al. 2001; Dickson et al. 2000). Several pieces of evidence suggest that soil C cycling has been altered by changes in litter production, particularly litter originating from fine roots. We have observed that elevated $\mathrm{CO}_{2}$ significantly increased fine root production, soil respiration (King et al. 2001), and the activity of enzymes involved with the degradation of plant and fungal cell wall (i.e., cellobiohydrolase and $\mathrm{N}$-acetylglucosamidase, respectively). These effects were largely eliminated by elevated $\mathrm{O}_{3}$ (King et al. 2001; Larson et al., in press). Greater rates of plant and fungal cell wall degradation under elevated $\mathrm{CO}_{2}$, along with greater soil $\mathrm{C}$ inputs and respiration, may be linked to changes in microbial community composition and rates of substrate metabolism (Sinsabaugh 1994; Carreiro et al. 2000).

Because plants are known to differ in their growth response to elevated $\mathrm{CO}_{2}$ and $\mathrm{O}_{3}$, we reasoned that species-specific differences in litter inputs would control the magnitude of the microbial response beneath plants grown under elevated $\mathrm{CO}_{2}$ and $\mathrm{O}_{3}$ (Hungate et al. 1996; Hättenschwiler and Körner 2000). Quaking aspen (Populus tremuloides Michx.) and paper birch (Betula papyrifera Marsh.) are early-successional species that are adapted to high light conditions and grow more quickly than the late-successional sugar maple (Acer saccharum Marsh). If microbial activity is primarily regulated by soil $\mathrm{C}$ inputs, then the effect of elevated $\mathrm{CO}_{2}$ and $\mathrm{O}_{3}$ on microbial metabolism would be greater for aspen and birch species than for maple.

We amended soils from our FACE experiment with ${ }^{13} \mathrm{C}$-labeled cellobiose and $N$-acetylglucosamine to determine how changes in plant litter inputs under elevated $\mathrm{CO}_{2}$ and $\mathrm{O}_{3}$ have altered microbial metabolism and the flow of $\mathrm{C}$ through the heterotrophic microbial community. We hypothesized that microbial metabolism of these substrates would parallel previously observed changes in cellobiohydrolase and $\mathrm{N}$-acetylglucosamidase activities, with greater rates of metabolism occurring beneath plants growing under elevated $\mathrm{CO}_{2}$. We also reasoned that $\mathrm{O}_{3}$ would dampen this effect, a pattern consistent with fine root litter production (King et al. 2001), soil respiration (King et al. 2001), and microbial enzyme activity (Larson et al., in press).

\section{Materials and methods}

Study site and sample collection

Our study was conducted at the FACE site located in Rhinelander, Wisconsin $\left(45^{\circ} 40.5^{\prime} \mathrm{N}, 89^{\circ} 37.5^{\prime} \mathrm{E}\right)$ (Dickson et al. 2000). This 32-ha facility consists of 12 circular, 30-m-diameter rings that are spaced $100 \mathrm{~m}$ apart to minimize between-ring drift of $\mathrm{CO}_{2}$ and $\mathrm{O}_{3}$. Each ring is split into three community types, and each ring section is planted with an equal density of trees. One half of each ring was planted with five aspen clones of varying sensitivity to $\mathrm{O}_{3}$; one quarter of each ring was planted with birch and aspen; the remaining quarter was planted with maple and aspen. A total of 670 trees (currently $\sim 2 \mathrm{~m}$ in height) were planted in each ring in 1997. This is a split-plot, randomized, complete block design, in which there are three replicates of factorial atmospheric $\mathrm{CO}_{2}$ and $\mathrm{O}_{3}$ treatments; the three tree communities split the $\mathrm{CO}_{2}-\mathrm{O}_{3}$ main plots.

The FACE system consists of a high-volume blower, a plenum pipe for air distribution and a circular arrangement of 32 vertical vent pipes that compose each FACE ring. $\mathrm{CO}_{2}$ and $\mathrm{O}_{3}$ treatments were applied during the growing season in 1998, 1999, and 2000. Elevated- $\mathrm{CO}_{2}$ rings were fumigated with $\sim 560 \mu \mathrm{CO}_{2} \mathrm{1}^{-1}$, which is $200 \mu \mathrm{CO}_{2} 1^{-1}$ above ambient atmospheric $\mathrm{CO}_{2}$. Elevated- $\mathrm{O}_{3}$ rings were fumigated with $\sim 55 \mathrm{nl} \mathrm{O}_{3} \mathrm{l}^{-1}$, or $20 \mathrm{nl} \mathrm{O}_{3} \mathrm{l}^{-1}$ above average ambient atmospheric $\mathrm{O}_{3}$. Monitoring and control equipment maintained target $\mathrm{CO}_{2}$ and $\mathrm{O}_{3}$ concentrations with real-time computer algorithms linked to analyzers by fiber-optic connections. A complete description of hardware and performance is found in Dickson et al. (2000).

Soils at the site are mixed, frigid, coarse loamy Alfic Haplorthods. The sandy loam A horizon $(\sim 15 \mathrm{~cm}$ thick) grades into a loamy B horizon ( $\sim 30 \mathrm{~cm}$ thick) and then into a sandy loam $\mathrm{C}$ horizon containing stratified sand and gravel. Physical and chemical soil properties are summarized in Table 1. In general, soil properties varied little across the site, but total soil $\mathrm{C}$ and $\mathrm{N}$ averaged slightly higher in the elevated $\mathrm{CO}_{2}$ and $\mathrm{CO}_{2}+\mathrm{O}_{3}$ treatments (Dickson et al. 2000).

In September 2000, we collected six soil cores $(3 \mathrm{~cm}$ in diameter and $10 \mathrm{~cm}$ in depth) at random locations from inside each ring section (i.e., split plot). Cores were composited by ring section, homogenized, transported to the laboratory on ice, and stored at $4^{\circ} \mathrm{C}$ prior to analysis.

\section{${ }^{13} \mathrm{C}$ labeling and incubation experiment}

Within $48 \mathrm{~h}$ of field collection, soil subsamples $(60 \mathrm{~g})$ were amended with tracer $\left(10 \mu \mathrm{g}{ }^{13} \mathrm{C} \mathrm{g}^{-1}\right)$ amounts of ${ }^{13} \mathrm{C}$-labeled substrates, which were delivered in $4 \mathrm{ml}$ deionized water. Thirty-six samples (one from each $\mathrm{CO}_{2} \times \mathrm{O}_{3} \times$ species treatment combination) were incubated with ${ }^{13} \mathrm{C}$-cellobiose $\left(100 \%{ }^{13} \mathrm{C}\right)$, and a duplicate set of 36 subsamples was incubated with ${ }^{13} \mathrm{C}$-labeled $N$-acetylglucosamine $\left(100 \%{ }^{13} \mathrm{C}\right)$. Amended soil was incubated at $19^{\circ} \mathrm{C}$ for $10 \mathrm{~h}$, a time period we had previously determined to be sufficient for microbial assimilation of the added labeled compounds. We also added deionized water to one additional subsample from each FACE ring to determine the natural abundance of ${ }^{13} \mathrm{C}$ in soil pools. Field soil moisture was determined by oven drying $\left(70^{\circ} \mathrm{C}\right)$ additional subsamples. All subsequent analyses were performed on these ${ }^{13} \mathrm{C}$-labeled and unlabeled soils. 
Table 1 Summary of physical and chemical soil properties prior to treatment (July 1997) at the free-air $\mathrm{CO}_{2}$ and $\mathrm{O}_{3}$ enrichment site in Rhinelander, Wisconsin. Values are means with SEMs in parentheses (King et al. 2000)

\begin{tabular}{|c|c|c|c|c|}
\hline \multirow[t]{2}{*}{ Treatment } & \multicolumn{2}{|c|}{ Ambient $\mathrm{O}_{3}$} & \multicolumn{2}{|c|}{ Elevated $\mathrm{O}_{3}$} \\
\hline & $\begin{array}{l}\text { Ambient } \\
\mathrm{CO}_{2}\end{array}$ & $\begin{array}{l}\text { Elevated } \\
\mathrm{CO}_{2}\end{array}$ & $\begin{array}{l}\text { Ambient } \\
\mathrm{CO}_{2}\end{array}$ & $\begin{array}{l}\text { Elevated } \\
\mathrm{CO}_{2}\end{array}$ \\
\hline \multicolumn{5}{|l|}{ Soil texture } \\
\hline$\%$ Sand & $\begin{array}{l}55.1 \\
(2.1)\end{array}$ & $\begin{array}{l}53.9 \\
(1.5)\end{array}$ & $\begin{array}{l}58.3 \\
(1.1)\end{array}$ & $\begin{array}{l}55.0 \\
(1.7)\end{array}$ \\
\hline$\%$ Silt & $\begin{array}{l}36.1 \\
(1.8)\end{array}$ & $\begin{array}{l}37.8 \\
(1.3)\end{array}$ & $\begin{array}{l}35.3 \\
(2.1)\end{array}$ & $\begin{array}{l}37.4 \\
(1.6)\end{array}$ \\
\hline$\%$ Clay & $\begin{array}{c}8.7 \\
(0.75)\end{array}$ & $\begin{array}{c}8.4 \\
(0.58)\end{array}$ & $\begin{array}{r}6.4 \\
(1.1)\end{array}$ & $\begin{array}{c}7.7 \\
(0.40)\end{array}$ \\
\hline Bulk density & $\begin{array}{c}1.27 \\
(0.08)\end{array}$ & $\begin{array}{c}1.30 \\
(0.08)\end{array}$ & $\begin{array}{c}1.32 \\
(0.09)\end{array}$ & $\begin{array}{c}1.43 \\
(0.06)\end{array}$ \\
\hline Total C ( $\left.\mathrm{g} \mathrm{C} \mathrm{kg}^{-1}\right)$ & $\begin{array}{l}15.4 \\
(1.6)\end{array}$ & $\begin{array}{l}16.8 \\
(1.9)\end{array}$ & $\begin{array}{l}16.0 \\
(1.8)\end{array}$ & $\begin{array}{l}13.1 \\
(1.2)\end{array}$ \\
\hline Total N ( $\left.\mathrm{g} \mathrm{N} \mathrm{kg}^{-1}\right)$ & $\begin{array}{c}1.2 \\
(0.1)\end{array}$ & $\begin{array}{c}1.3 \\
(0.2)\end{array}$ & $\begin{array}{l}1.2 \\
(0.2)\end{array}$ & $\begin{array}{l}1.0 \\
(0.0)\end{array}$ \\
\hline $\mathrm{C}: \mathrm{N}$ & $\begin{array}{l}12.9 \\
(0.5)\end{array}$ & $\begin{array}{l}12.4 \\
(0.2)\end{array}$ & $\begin{array}{l}13.5 \\
(0.4)\end{array}$ & $\begin{array}{l}12.8 \\
(0.4)\end{array}$ \\
\hline
\end{tabular}

Microbial respiration

Microbial respiration was determined $1 \mathrm{~h}$ after substrate addition by placing the amended soils in 0.95-1 mason jars with airtight lids and rubber septa for gas sampling. Using a gas-tight syringe, we withdrew a 30-ml aliquot of air from the headspace of each incubation vessel. We determined headspace $\mathrm{CO}_{2}$ concentration and the $\delta^{13} \mathrm{C}$ of $\mathrm{CO}_{2}$ using a Finnigan Delta Plus isotope ratio mass spectrometer (IRMS) with a Conflo II interface (Thermofinnigan, Bremen). The headspace concentration of $\mathrm{CO}_{2}$ and $\delta^{13} \mathrm{C}$ was measured 4 times at 1 -h intervals during the first $4 \mathrm{~h}$ of the experiment. The rate of respiration was calculated using the time-linear change in headspace $\mathrm{CO}_{2}\left(\mu \mathrm{CO}_{2} \mathrm{~h}^{-1}\right)$ divided by the dry mass of soil. We determined the amount of substrate ${ }^{13} \mathrm{C}$ respired by multiplying the mass of $\mathrm{C}$ respired by atom $\%$ excess ${ }^{13} \mathrm{C}$; the natural abundance of ${ }^{13} \mathrm{C}$ in microbial respiration was determined using the samples amended with deionized water. Analytical error for the mass spectrometer, based upon replicate measurements of a single homogenized soil sample, had a $1 \%$ coefficient of variation. Analysis of internal standards indicated an analytical error of $<5 \%$.

Dissolved organic $\mathrm{C}$ and soil organic matter

Subsamples $(20 \mathrm{~g})$ from each of the 72 amended soils were extracted with $40 \mathrm{ml}$ of $0.5 \mathrm{M} \mathrm{K}_{2} \mathrm{SO}_{4}$ to determine dissolved organic $\mathrm{C}$ (DOC). We evaporated extracts and determined $\mathrm{C}$ and $\delta^{13} \mathrm{C}$ by mass-spectrometry using a CE Elantech NC2500 interfaced to a Finnigan Delta Plus IRMS. The remaining extracted soil was oven dried and pulverized with a ball mill. The $\mathrm{C}$ and ${ }^{13} \mathrm{C}$ of the extracted soil was determined by mass-spectrometry as described above. These values correspond to the amount of labeled substrate that had been incorporated into the soil organic matter (SOM).

The excess ${ }^{13} \mathrm{C}$ recovered in $\mathrm{SOM}$ and $\mathrm{DOC}$ was determined by multiplying the concentration of $\mathrm{C}\left(\mu \mathrm{g} \mathrm{C} \mathrm{g}^{-1}\right)$ by the mass of soil $(\mathrm{g})$ and its atom $\%$ excess ${ }^{13} \mathrm{C}$ (measured atom $\%{ }^{13} \mathrm{C}$ minus natural abundance atom $\%^{13} \mathrm{C}$ ). The natural abundance of ${ }^{13} \mathrm{C}$ was determined from samples receiving only deionized water. Excess ${ }^{13} \mathrm{C}\left(\mu \mathrm{g}{ }^{13} \mathrm{C}\right)$ represents the total amount of ${ }^{13} \mathrm{C}$ recovered in SOM and DOC for each soil sample.
${ }^{13} \mathrm{C}$-phospholipid fatty acid analysis

At the end of the 10-h incubation, soil subsamples (10 g) were placed at $-70^{\circ} \mathrm{C}$ overnight, and then freeze-dried for phospholipid fatty acid (PLFA) analysis. Lipids were extracted with a singlephase solvent system modified to include a $\mathrm{PO}_{4}{ }^{3-}$ buffer (Bligh and Dyer 1959; White et al. 1979). Silicic acid column chromatography was used to fractionate the total lipid extract into neutral, glyco- and polar lipids (Gehron and White 1983). Silicic acid columns were placed on a vacuum manifold system to facilitate elution (Burdick and Jackson, Muskegon, Mich.). Polar lipids were then subjected to a mild alkaline reagent that contained methanol to form fatty acid methyl esters (FAMEs), which were separated and quantified using a Finnigan Delta plus mass spectrometer with a GC/C III interface (Thermofinnigan) coupled to a HP 5973 GC (Agilent Technologies, Palo Alto, Calif.) (sensu Boschker et al. 1998). Chromatographic peaks were quantified based on a 19:0 standard, and double-bond locations in monounsaturated PLFA were confirmed by GC-MS analysis of their dimethyldisulfide adducts. A standard qualitative bacterial FAME mix (Matreya, Pleasant Gap, Pa.) also was used to identify and quantify FAMEs by chromatographic retention time (Ringelberg et al. 1997). The abundance and $\delta^{13} \mathrm{C}$ of individual FAMEs were expressed as $\mu \mathrm{g}$ PLFA C g ${ }^{-1}$ dry soil and as $\mu$ g excess ${ }^{13} \mathrm{C}$. Fatty acid nomenclature follows Ratledge and Wilkinson (1988).

The polyenoic, unsaturated PLFAs $(18: 2 \omega 6,18: 1 \omega 9 \mathrm{c}$, and 18:3 13 ) are biomarkers for soil fungi (Federle et al. 1986), and the monoenoic and cyclopropane unsaturated PLFAs (16:1 $1 \omega 5 \mathrm{c}$, $16: 1 \omega 7 \mathrm{c}, 16: 1 \omega 9 \mathrm{c}$, a16:0, cy17:0, 18:1 $1 \omega 7 \mathrm{c}$ and cy19:0a) are characteristic of Gram-negative bacteria. Straight-chain PLFAs that are non-specific bacterial biomarkers include 14:0, 16:0, and 18:0. We used branched, saturated PLFAs (10me16:0, 15:0, i15:0, a15:0, i16:0, 17:0, i17:0 and a17:0) to indicate the presence of Gram-positive bacteria in soil (Frostegård and Bååth 1994; Grayston et al. 2000). We used total PLFA as an index of living microbial biomass.

The relative abundance of each PLFA (\% of total PLFA C) was used to compare microbial community composition among treatments. The excess ${ }^{13} \mathrm{C}$ recovered in each PLFA was determined by multiplying the mass of PLFA C $\left(\mu \mathrm{g} \mathrm{C} \mathrm{g}^{-1}\right)$ by the mass of soil $(\mathrm{g})$ and its atom $\%$ excess ${ }^{13} \mathrm{C}$ (measured atom $\%{ }^{13} \mathrm{C}$ minus natural abundance atom $\%{ }^{13} \mathrm{C}$ ). Natural abundance of ${ }^{13} \mathrm{C}$ in each PLFA was determined from samples receiving only deionized water. We used the ratio of ${ }^{13} \mathrm{C}$ in fungal versus bacterial PLFAs to assess whether our experimental treatments altered the metabolic activity of fungi, relative to bacteria (Bardgett et al 1996).

\section{Statistical analyses}

We used an ANOVA for a split-plot, randomized complete block design to test the influence of $\mathrm{CO}_{2}, \mathrm{O}_{3}$ and species on the amount of ${ }^{13} \mathrm{C}$ recovered in soil respiration, PLFAs, DOC and SOM. Separate analyses were conducted for samples amended with cellobiose and $\mathrm{N}$-acetylglucosamine. We used an identical ANOVA model to determine the influence of our experimental treatments on total PLFA and the proportion of PLFAs that are biomarkers for Grampositive bacteria, Gram-negative bacteria, and fungi. Treatment effects were considered significant if $P<0.05$

\section{Results}

Total recovery of ${ }^{13} \mathrm{C}$-cellobiose averaged $76 \%$ across $\mathrm{CO}_{2}-\mathrm{O}_{3}$ treatment combinations, and average recovery of isotope in the ${ }^{13} \mathrm{C}-\mathrm{N}$-acetylglucosamine labeled samples averaged $85 \%$ (Table 2). Total recovery of isotope did not differ significantly among any treatment or treatment combination.

The addition of ${ }^{13} \mathrm{C}$-labeled cellobiose or $\mathrm{N}$-acetylglucosamine did not increase the rate of microbial respira- 
Table 2 Summary of ${ }^{13} \mathrm{C}$ recovered from soils amended with cellobiose and $N$-acetylglucosamine by soil pool. Values are treatment means with SEMs in parentheses. Means in a row with different letters are significantly different. SOM Soil organic matter, $D O C$ dissolved organic C, PLFA Phospholipid fatty acid

\begin{tabular}{|c|c|c|c|c|c|c|}
\hline \multirow[t]{2}{*}{$\begin{array}{l}\text { Treatment } \\
\text { Substrate }\end{array}$} & & $\begin{array}{l}\text { Ambient } \\
\text { Mean (SEM) }\end{array}$ & $\begin{array}{l}+\mathrm{CO}_{2} \\
\text { Mean (SEM) }\end{array}$ & $\begin{array}{l}+\mathrm{O}_{3} \\
\text { Mean (SEM) }\end{array}$ & $\begin{array}{l}+\mathrm{CO}_{2}+\mathrm{O}_{3} \\
\text { Mean }(\mathrm{SEM})\end{array}$ & $P$ \\
\hline & & \multicolumn{5}{|l|}{ Recovery (\%) } \\
\hline \multirow[t]{5}{*}{ Cellobiose } & Respiration & $6.16 \mathrm{a}(0.43)$ & $7.34 b(0.43)$ & $5.87 \mathrm{a}(0.46)$ & $5.74 a(0.43)$ & 0.0121 \\
\hline & SOM & $60.55(1.72)$ & $66.35(2.48)$ & $60.16(3.21)$ & $66.02(3.87)$ & 0.0548 \\
\hline & DOC & $4.08(0.40)$ & $3.00(0.28)$ & $3.64(0.70)$ & $5.13(0.78)$ & 0.3916 \\
\hline & PLFA & $2.51(0.23)$ & $3.22(0.26)$ & $2.79(0.27)$ & $3.28(0.27)$ & 0.1760 \\
\hline & Total & 73.30 (1.69) & $79.91(2.60)$ & 72.46 (3.78) & 80.16 (4.05) & 0.1107 \\
\hline \multirow[t]{5}{*}{$N$-Acetylglucosamine } & Respiration & 5.81a (2.10) & $8.09 b(0.57)$ & $4.84 \mathrm{a}(0.82)$ & 5.75a (0.86) & 0.0021 \\
\hline & SOM & $46.26(1.29)$ & 44.14 (1.57) & $45.79(1.51)$ & $44.06(1.28)$ & 0.1507 \\
\hline & DOC & $7.94(0.50)$ & $8.62(0.20)$ & $7.25(0.37)$ & $8.52(0.16)$ & 0.3535 \\
\hline & PLFA & 27.51(0.59) & $26.48(1.78)$ & $25.28(2.10)$ & $25.83(2.13)$ & 0.4588 \\
\hline & Total & 86.25 (2.39) & 85.38 (3.06) & 82.57 (1.77) & 82.31 (1.13) & 0.2531 \\
\hline
\end{tabular}

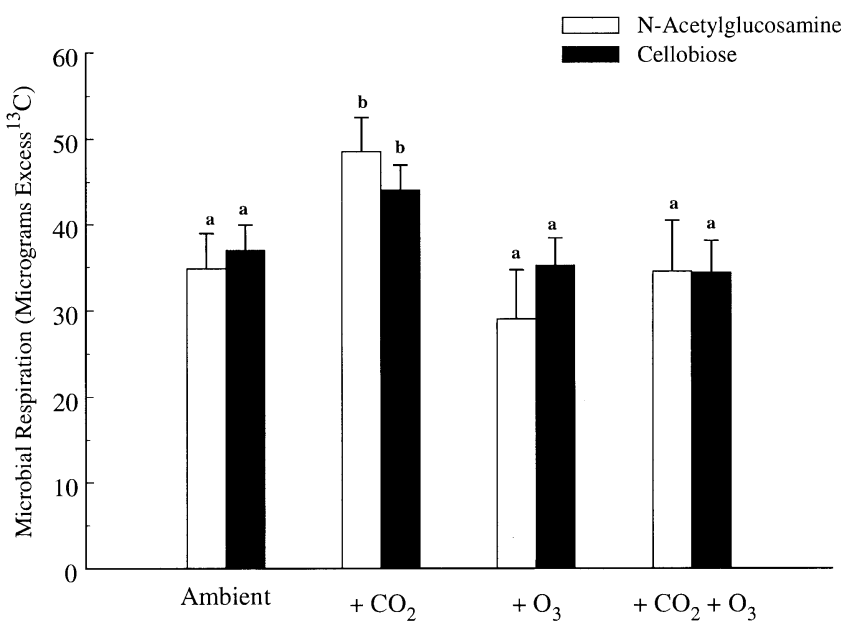

Fig. 1 Mean excess ${ }^{13} \mathrm{C}$-cellobiose and $\mathrm{N}$-acetylglucosamine recovered $(\mu \mathrm{g})$ in microbial respiration $(n=9)$. The length of each bar is $1 \mathrm{SE}$, and treatment means for each substrate that have the same letter are not significantly different

tion $\left(2 \mu \mathrm{g} \mathrm{C}-\mathrm{CO}_{2} \mathrm{~h}^{-1} \mathrm{~g}^{-1}\right)$ relative to samples receiving deionized water, indicating that addition of the ${ }^{13} \mathrm{C}$ labeled substrates did not stimulate microbial activity. The amount of ${ }^{13} \mathrm{C}$ recovered in microbial respiration increased beneath plants exposed to elevated $\mathrm{CO}_{2}$ by $29 \%$, but elevated $\mathrm{O}_{3}$ dampened this response (Fig. 1); this was true for samples amended with cellobiose or $\mathrm{N}$-acetylglucosamine. Although the magnitude of the $\mathrm{CO}_{2}$ effect varied among species, we found no significant effect of species on rates of microbial respiration in soil amended with either substrate (data not shown). Nonetheless, microbial communities beneath aspen and aspenbirch exposed to elevated $\mathrm{CO}_{2}$ respired greater amounts of ${ }^{13} \mathrm{C}-\mathrm{CO}_{2}$ than those beneath aspen-maple; this was true for both cellobiose and $N$-acetylglucosamine. Average recovery of both substrates in microbial respiration beneath aspen-maple ranged from 28 to $34 \mu \mathrm{g}{ }^{13} \mathrm{C}$, whereas the range broadened for aspen $(34-49 \mu \mathrm{g})$ and aspen-birch $(40-50 \mu \mathrm{g})$.

The greatest proportion of both labeled substrates was recovered in SOM (Table 2). Recovery of ${ }^{13} \mathrm{C}$ in SOM

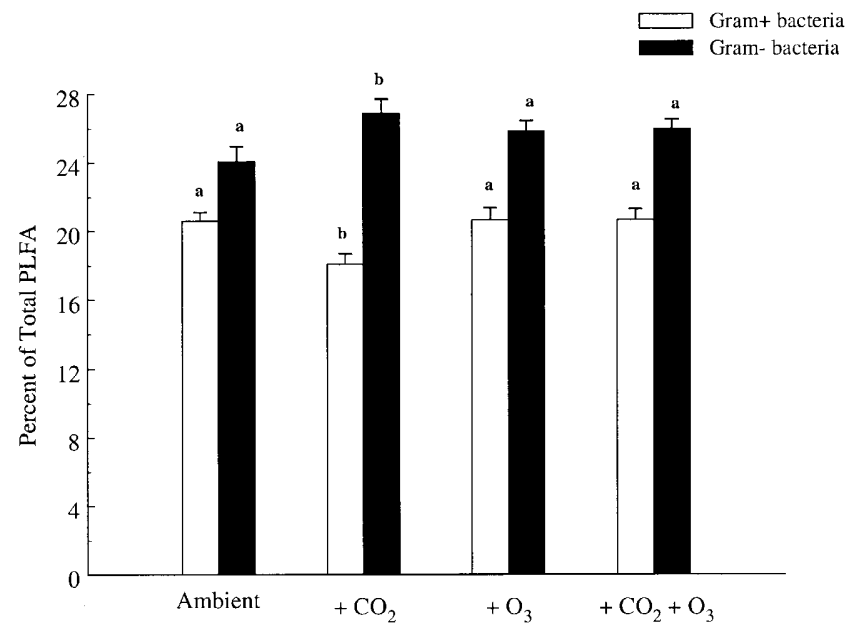

Fig. 2 The abundance of Gram-positive (10me16:0, 15:0, i15:0, a15:0, i16:0, 17:0, i17:0, a17:0) and Gram-negative (16:1w5c, 16:1w7c, 16:1w9c, a16:0, cy17:0, 18:1w7c, cy19:0a) bacterial phospholipid fatty acids (PLFAs) in ${ }^{13} \mathrm{C}$-cellobiose-amended soil. The length of each bar is $1 \mathrm{SE}$, and treatment means for each bacterial group that have the same letter are not significantly different

averaged $63 \%$ in cellobiose-amended soil and $45 \%$ in soil amended with $\mathrm{N}$-acetylglucosamine; values were not significantly influenced by $\mathrm{CO}_{2}, \mathrm{O}_{3}$, species, or their interactions. Recovery of ${ }^{13} \mathrm{C}$-cellobiose in $\mathrm{DOC}$ ranged from 3 to $5 \%$ among treatments, and mean recovery varied from 7 to $9 \%$ in soils labeled with ${ }^{13} \mathrm{C}-\mathrm{N}$-acetylglucosamine (Table 2). For each substrate, ${ }^{13} \mathrm{C}$ recovery in DOC did not differ significantly among treatments.

\section{Community composition and substrate metabolism}

In ${ }^{13} \mathrm{C}$-cellobiose-amended soil, the relative proportion of Gram-positive bacterial PLFAs decreased, whereas the relative proportion of Gram-negative bacterial PLFAs increased beneath plants fumigated with $\mathrm{CO}_{2}$ (Fig. 2). This effect was dampened by elevated $\mathrm{O}_{3}$, because the relative proportion of Gram-positive and Gram-negative bacterial PLFAs beneath plants fumigated with $\mathrm{CO}_{2}$ and $\mathrm{O}_{3}$ was similar to the ambient treatment. We also found that reductions in soil fungi beneath ele- 


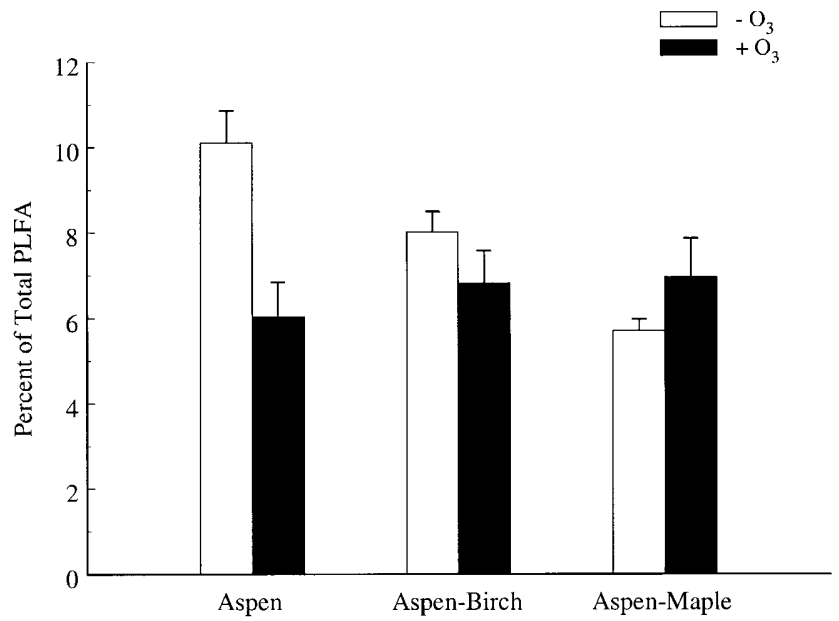

Fig. 3 The influence of $\mathrm{O}_{3}$ and species on the abundance of fungal PLFA in ${ }^{13} \mathrm{C}$-cellobiose-amended soil. Values are treatment means and bars represent $1 \mathrm{SE}$. Elevated $\mathrm{O}_{3}$ significantly lowered fungal PLFA in the aspen and birch-aspen treatments, but elevated $\mathrm{O}_{3}$ had no effect on fungal PLFA in the maple-aspen treatment
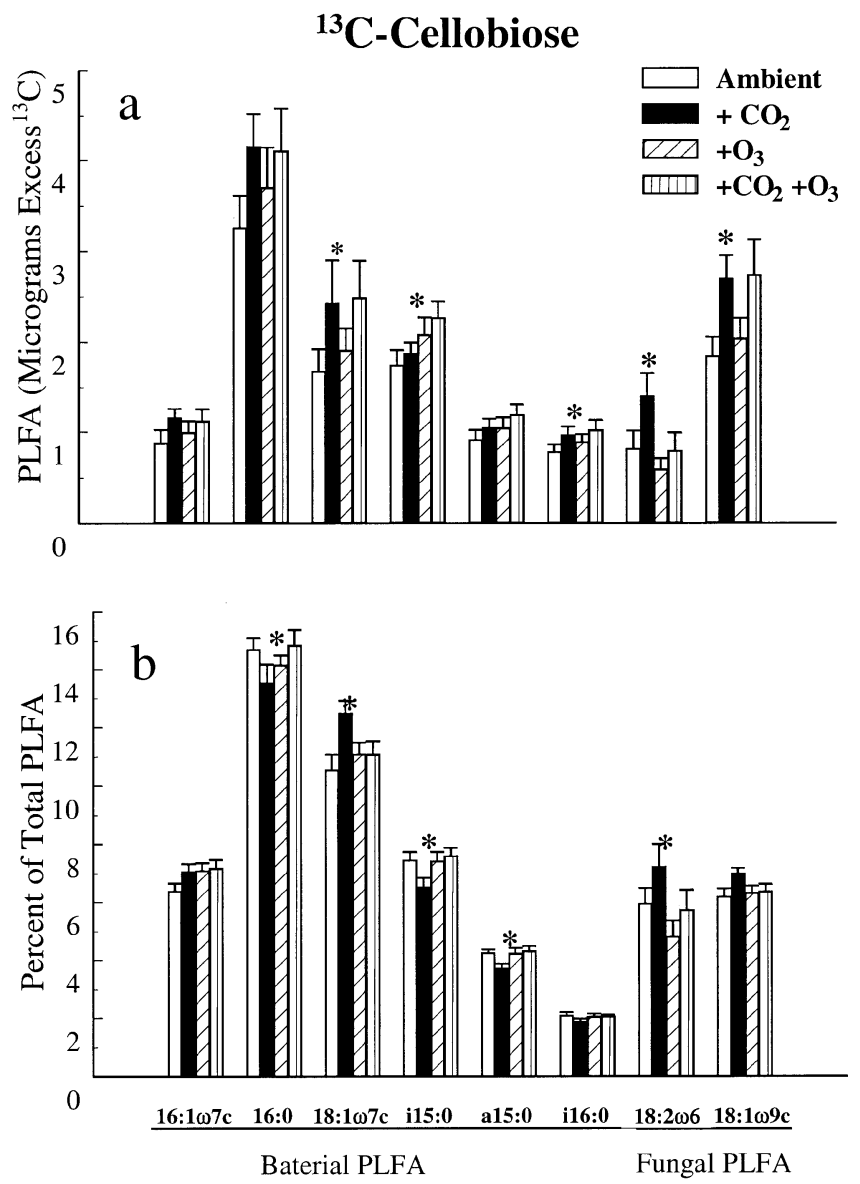

Fig. 4 The amount of excess ${ }^{13} \mathrm{C}$ recovered in bacterial and fungal PLFA in soil labeled with ${ }^{13} \mathrm{C}$-cellobiose (a), and the relative proportion of bacterial and fungal PLFAs in ${ }^{13} \mathrm{C}$-cellobiose-labeled soil (b). Individual values are $\mathrm{CO}_{2} \times \mathrm{O}_{3}$ interaction means. Each PLFA identified with an asterisk contained significantly different amounts of ${ }^{13} \mathrm{C}$ (a) or differed in their proportion among the $\mathrm{CO}_{2} \times \mathrm{O}_{3}$ treatment combinations (see text for details)
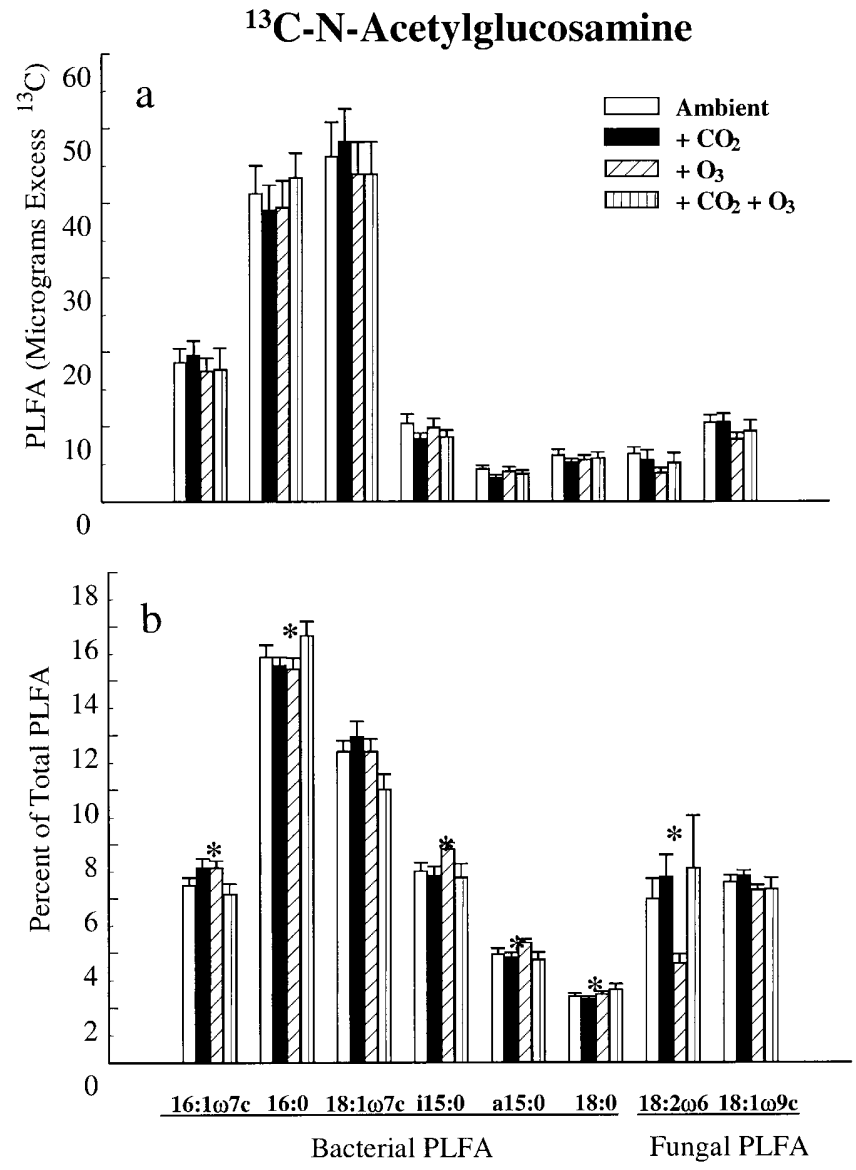

Fig. 5 The amount of excess ${ }^{13} \mathrm{C}$ recovered in bacterial and fungal PLFA in soil labeled with ${ }^{13} \mathrm{C}-N$-acetylglucosamine (a), and the relative proportion of bacterial and fungal PLFAs in ${ }^{13} \mathrm{C}-\mathrm{N}$-acetylglucosamine-labeled soil (b). Individual values are $\mathrm{CO}_{2} \times \mathrm{O}_{3}$ interaction means. Each PLFA identified with an asterisk contained significantly different amounts of ${ }^{13} \mathrm{C}$ (a) or differed in their proportion among the $\mathrm{CO}_{2} \times \mathrm{O}_{3}$ treatment combinations (see text for details)

vated $\mathrm{O}_{3}$ were evident for some tree species, as there was less fungal PLFA beneath aspen and aspen-birch growing under elevated $\mathrm{O}_{3}$ than ambient $\mathrm{O}_{3}$ (Fig. 3). Fungal PLFA in the aspen-maple treatment, on the other hand, was not affected by $\mathrm{O}_{3}$ (Fig. 3). In contrast, we did not observe treatment differences in the relative proportion of fungal, Gram-positive, or Gram-negative bacterial PLFA in soils amended with ${ }^{13} \mathrm{C}-\mathrm{N}$-acetylglucosamine (data not shown).

Nine PLFAs contained $80 \%$ of excess ${ }^{13} \mathrm{C}$ recovered in PLFAs in both cellobiose- and $\mathrm{N}$-acetylglucosamineamended soil. These PLFAs included biomarkers for Gram-positive bacteria (a15:0, i15:0, i16:0), Gram-negative bacteria $(16: 1 \omega 7 \mathrm{c}, 18: 1 \omega 7 \mathrm{c})$, non-specific bacteria $(16: 0,18: 0)$, and fungi $(18: 2 \omega 6,18: 1 \omega 9 \mathrm{c})$. In cellobioseamended soil, five of these PLFAs $(18: 1 \omega 7 \mathrm{c}$, i15:0, i16:0, 18:2 $\omega 6,18: 1 \omega 9 \mathrm{c})$ contained a greater proportion of ${ }^{13} \mathrm{C}$ beneath plants exposed to elevated $\mathrm{CO}_{2}$ (Fig. 4a). Lower recovery of ${ }^{13} \mathrm{C}$-cellobiose in 18:2 $\omega 6$ was found beneath plants exposed to elevated $\mathrm{O}_{3}$, compared to 


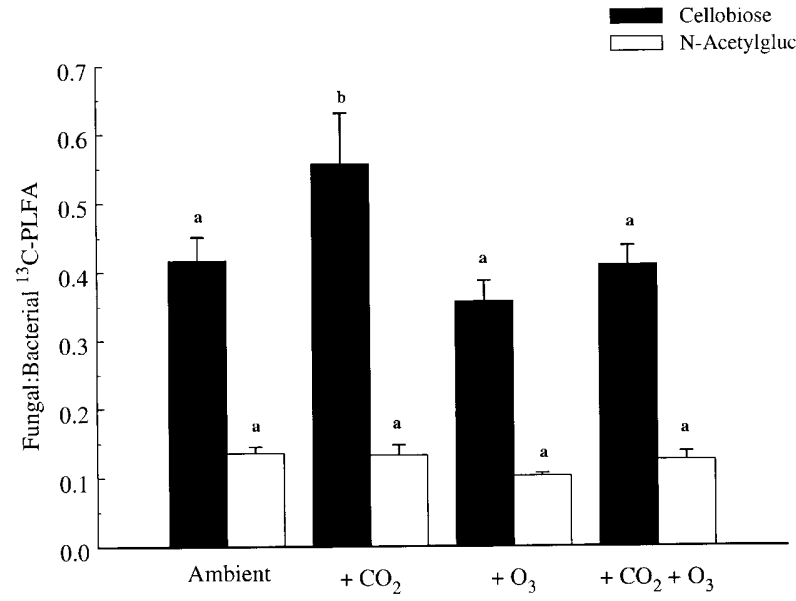

Fig. 6 The ratio of ${ }^{13} \mathrm{C}$ recovered in fungal versus bacterial PLFAs. Values are $\mathrm{CO}_{2} \times \mathrm{O}_{3}$ interaction means for soil labeled with ${ }^{13} \mathrm{C}$-cellobiose (closed bars) or ${ }^{13} \mathrm{C}-\mathrm{N}$-acetylglucosamine (open bars). Bars are $1 \mathrm{SE}$, and means for each substrate that have the same letter are not significantly different

ambient $\mathrm{O}_{3}$, and $\mathrm{O}_{3}$ also dampened the positive effect of $\mathrm{CO}_{2} \cdot \mathrm{O}_{3}$ had a contrasting affect on i15:0; more ${ }^{13} \mathrm{C}$-cellobiose was metabolized beneath plants exposed to elevated $\mathrm{O}_{3}$. In $\mathrm{N}$-acetylglucosamine-amended soil, identical analyses performed on the eight individual PLFAs representing $80 \%$ of total PLFA indicated that $\mathrm{CO}_{2}$ and $\mathrm{O}_{3}$ did not affect the recovery of ${ }^{13} \mathrm{C}$ in any individual PLFA (Fig. 5a).

Microbial community composition was significantly influenced by a $\mathrm{CO}_{2} \times \mathrm{O}_{3}$ interaction (Figs. $4 \mathrm{~b}, 5 \mathrm{~b}$ ). In general elevated $\mathrm{CO}_{2}$ increased the abundance of fungal PLFAs in both cellobiose- and $N$-acetylglucosamineamended soil, but some increases were not statistically significant. Bacterial PLFAs exhibited mixed responses, wherein the elevated- $\mathrm{CO}_{2}$ treatment increased $(16: 1 \omega 7 \mathrm{c}, 18: 1 \omega 7 \mathrm{c})$ and decreased $(16: 0, \mathrm{i} 15: 0, \mathrm{a} 15: 0)$ their relative abundance (Figs. $4 \mathrm{~b}, 5 \mathrm{~b}$ ). The response of PLFAs to the $\mathrm{O}_{3}$ and $\mathrm{CO}_{2}+\mathrm{O}_{3}$ treatments was variable.

The ratio of fungal to bacterial ${ }^{13} \mathrm{C}$-PLFA indicated that fungi metabolized proportionately more cellobiose than $\mathrm{N}$-acetylglucosamine, despite similarities in the relative abundance of total fungal PLFA. We found that the fungal:bacterial ${ }^{13}$ C-PLFA ratio for cellobioseamended soil was greater beneath plants growing under elevated $\mathrm{CO}_{2}$, and that this effect was also dampened by elevated $\mathrm{O}_{3}$ (Fig. 6). Treatment differences in fungal: bacterial ${ }^{13}$ C-PLFA did not occur in $N$-acetylglucosamine-amended soil, and may in part be due to lower fungal:bacterial activity (Fig. 6). Mean fungal:bacterial ${ }^{13} \mathrm{C}$-PLFA in $\mathrm{N}$-acetylglucosamine-amended soil ( 0.12$)$ was much lower than recovery fungal:bacterial ${ }^{13} \mathrm{C}$-PLFA $(\sim 0.44)$ in cellobiose-amended soil. Along with microbial respiration, the magnitude of these responses varied with species, with early-successional species exhibiting greater fungal:bacterial ${ }^{13} \mathrm{C}$-PLFA than the late-successional maple.

\section{Discussion}

Our study demonstrates that microbial communities beneath plants growing under elevated $\mathrm{CO}_{2}$ respired greater amounts of ${ }^{13} \mathrm{C}$-labeled cellobiose and $\mathrm{N}$-acetylglucosamine, indicating altered rates of microbial metabolism driven by changes in litter production. Greater plant growth under elevated $\mathrm{CO}_{2}$ is likely to provide more organic substrates for microbial metabolism in soil, fueling more rapid rates of soil C cycling (Zak et al. 2000). Higher rates of soil respiration in forests and grasslands exposed to elevated $\mathrm{CO}_{2}$ are frequently reported (Hungate et al. 1997; Edwards and Norby 1998; Pregitzer et al. 2000), and signal increases in root biomass (Edwards and Norby 1998), fine root production production/ mortality (Matamala and Schlesinger 2000; King et al. 2001), and microbial activity (Zak et al. 1993; Hungate et al. 1997). We observed that microbial respiration was $29 \%$ greater beneath plants growing under elevated $\mathrm{CO}_{2}$. Moreover, the effect of $\mathrm{CO}_{2}$ was similar among plant species, yet the magnitude of the $\mathrm{CO}_{2}$ effect varied with species. Production of ${ }^{13} \mathrm{C}-\mathrm{CO}_{2}$ was greatest beneath aspen and aspen-birch growing under elevated $\mathrm{CO}_{2}$, compared with aspen-maple, but this was not statistically significant. Moreover, the effect of elevated $\mathrm{CO}_{2}$ was generally dampened by elevated $\mathrm{O}_{3}$, a response identical to that of soil enzyme activity (Larson et al., in press) and fine root production/mortality in our experiment (King et al. 2001).

$\mathrm{N}$-acetylglucosamine was utilized for biosynthesis to a greater extent than cellobiose, as evidenced by greater incorporation of ${ }^{13} \mathrm{C}$ into PLFA in soil amended with $\mathrm{N}$-acetylglucosamine than in soil amended with cellobiose. We amended soils with $N$-acetylglucosamine because we had previously observed greater $N$-acetylglucosimidase activity beneath plants grown under elevated $\mathrm{CO}_{2}$, which indicated higher rates of fungal or bacterial cell wall degradation (Larson et al., in press). Although microbial respiration of $\mathrm{N}$-acetylglucosamine increased beneath plants growing under elevated $\mathrm{CO}_{2}$, the amounts of ${ }^{13} \mathrm{C}$ incorporated into fungal and bacterial PLFAs increased proportionately in $N$-acetylglucosamine metabolism by these organisms. This was not the case for cellobiose metabolism, because fungal PLFAs contained more ${ }^{13} \mathrm{C}$ than bacterial PLFAs. We cannot determine how the metabolism of $\mathrm{N}$-acetylglucosamine differed physiologically from cellobiose; however, it is clear that changes in the amounts and types of substrates entering soil under elevated $\mathrm{CO}_{2}$ or $\mathrm{O}_{3}$ influenced microbial metabolism and soil C flow.

The ratio of ${ }^{13} \mathrm{C}$-cellobiose recovered in fungal:bacterial ${ }^{13} \mathrm{C}$-PLFA increased from 0.5 to 0.7 in soils beneath plants growing under elevated $\mathrm{CO}_{2}$. Like microbial respiration, this response was dampened by elevated $\mathrm{O}_{3}$. In cellobiose-amended soil, higher fungal:bacterial ${ }^{13} \mathrm{C}$-PLFA ratios corroborate reports that arbuscular mycorrhizal fungal biomass increases with $\mathrm{CO}_{2}$ enrichment (Rillig et al. 2000), that fungal species composition shifts in favor of fungi that decompose cellulose (Jones 
et al. 1998), and that fungi are more strongly stimulated by altered plant growth under elevated $\mathrm{CO}_{2}$ than bacteria (Rillig 2000). Our experiment complements these data by demonstrating that the proportion of cellobiose metabolized by fungi increased to a greater extent than bacteria in soil beneath plants exposed to elevated $\mathrm{CO}_{2}$.

We also found that elevated $\mathrm{CO}_{2}$ altered the composition of microbial communities without changing microbial biomass (i.e., total PLFA). In cellobiose-amended soil, PLFA biomarkers beneath plants growing under elevated $\mathrm{CO}_{2}$ exhibited a proportional decrease in Grampositive PLFAs and a proportional increase in Gramnegative PLFAs. Bruce et al. (2000) used a different technique to assess microbial community composition (i.e., DGGE) and did not detect a change in bacterial communities from $\mathrm{CO}_{2}$ exposure. However, these investigators used a model ecosystem that was exposed to $\mathrm{CO}_{2}$ for a short period (i.e., 38 weeks), thus making direct comparison with a FACE experiment difficult. A greater abundance of Gram-negative bacteria could occur if processes such as nitrification (Hungate et al. 1996; Holmes and Zak, in review) or symbiotic $\mathrm{N}$ fixation (Hungate et al. 1999), or decomposition by Gram-negative bacteria are enhanced when plants are grown under elevated $\mathrm{CO}_{2}$. It is interesting that a greater Gram-negative bacterial biomass was balanced by a lower Gram-positive biomass, resulting in no net change in total bacterial PLFA. Other field experiments also have shown that elevated $\mathrm{CO}_{2}$ does not alter total microbial biomass in pine forest (Allen et al. 2000), tallgrass prairie (Rice et al. 1994), and annual grassland (Hungate et al. 1997) ecosystems, although these researchers did not employ PLFAs to measure (live) microbial biomass.

Microbial response to elevated $\mathrm{CO}_{2}$ was attenuated by elevated $\mathrm{O}_{3}$, most strongly evidenced by the response of microbial respiration to our experimental treatments. We previously observed that elevated $\mathrm{O}_{3}$ dampened the effect of elevated $\mathrm{CO}_{2}$ on fine root biomass, soil respiration, and extracellular enzyme activity (King et al. 2001; Larson et al., in press). These responses may be linked to a decline in $\mathrm{C}$ flow from the rhizosphere to fungi and bacteria when plants are exposed to high concentrations of $\mathrm{O}_{3}$ (Yoshida et al. 2001). Elevated $\mathrm{O}_{3}$ has been observed to reduce litter quality and rates of decay (Findlay et al. 1996), microbial biomass (Islam et al. 2000), and fungal biovolume (Carreiro et al. 1999). These impacts on microbial community composition and activity could lead to changes in plant nutrition, plant competition, and species composition (Yoshida et al. 2001). We suggest that greater soil $\mathrm{C}$ inputs beneath plants exposed to elevated $\mathrm{CO}_{2}$ resulted in greater microbial activity, and that elevated $\mathrm{O}_{3}$ eliminated this effect across species by attenuating the positive effect of $\mathrm{CO}_{2}$ on soil $\mathrm{C}$ inputs.

Aboveground responses to $\mathrm{CO}_{2}$ and $\mathrm{O}_{3}$ are often species specific (Broadmeadow and Jackson 2000; DeLucia and Thomas 2000; Hättenschwiler and Körner 2000; Medlyn et al. 2001). Thus, we studied how forest species influenced belowground responses to these trace gases. We found that $\mathrm{CO}_{2}$ and $\mathrm{O}_{3}$ altered microbial community composition and function beneath aspen and aspen-birch. The effect of treatments on microbial respiration was similar for all species, yet recovery of ${ }^{13} \mathrm{C}-\mathrm{CO}_{2}$ beneath aspen and aspen-birch was greater than beneath aspenmaple. Similarly, beneath aspen and aspen-birch, fungal abundance declined with elevated $\mathrm{O}_{3}$, whereas $\mathrm{O}_{3}$ did not reduce fungal abundance beneath aspen-maple. Our results demonstrate that 3 years of $\mathrm{O}_{3}$ exposure reduced the relative abundance of fungi and attenuated the positive effect of $\mathrm{CO}_{2}$ on microbial respiration beneath early-successional tree species. Therefore, the microbial community beneath forests dominated by early-successional tree species may be more sensitive to elevated atmospheric $\mathrm{CO}_{2}$ and $\mathrm{O}_{3}$ than forests dominated by late-successional tree species.

In summary, changes in plant growth in response to our experimental treatments elicited clear changes in the metabolism and composition of soil microbial communities. For example, elevated atmospheric $\mathrm{CO}_{2}$ increased the rates at which cellobiose and $N$-acetylglucosamine were metabolized by soil microorganisms, especially beneath early-successional forest species. Changes in cellobiose metabolism resulted from an increase in fungal metabolism, whereas increases in $\mathrm{N}$-acetylglucosamine metabolism likely resulted from a proportional increase in the activity of both soil bacteria and fungi. Our results indicate that increases in plant litter production under elevated $\mathrm{CO}_{2}$ may be counterbalanced by more rapid rates of litter degradation, which ultimately return photosynthetically fixed $\mathrm{C}$ to the atmosphere. Consistent with changes in fine root litter and the activity of cellobiohydrolase and $\mathrm{N}$-acetylglucosamidase, enhanced rates of substrate metabolism under elevated $\mathrm{CO}_{2}$ were eliminated by elevated $\mathrm{O}_{3}$. Moreover, we underscore the importance of understanding belowground responses to elevated $\mathrm{O}_{3}$. Our results demonstrate that enhanced fungal activity beneath plants growing under elevated $\mathrm{CO}_{2}$ is not evident when plants are also exposed to high concentrations of $\mathrm{O}_{3}$.

Acknowledgements The authors gratefully acknowledge financial support by the Department of Energy Program for Ecosystem Research (DE-FG02-93ER6166), the USDA-FS Northcentral Forest Experiment Station, and USDA Soil Biology Program. Matt Tomlinson, Matthew Bokach, and Haegeun Chung provided field and laboratory assistance. We also thank Aaron Peacock and associates at the Center for Environmental Biotechnology for their helpful instruction with PLFAs.

\section{References}

Allen AS, Andrews JA, Finzi AC, Matamala R, Richter DD, Schlesinger WH (2000) Effects of free-air $\mathrm{CO}_{2}$ enrichment (FACE) on belowground processes in a Pinus taeda forest. Ecol Appl 10:437-448

Bardgett RD, Hobbs PJ, Frostegård A (1996) Changes in soil fungal:bacterial biomass ratios following reductions in the intensity of management of an upland grassland. Biol Fertil Soils 22:261-264

Barnola JM, Anklin M, Porheron J, Raynaud D, Schwander J, Stauffer BTI (1995) $\mathrm{CO}_{2}$ evolution during the last millennium as recorded by Antarctic and Greenland ice. Tellus B 47: 264-272 
Berntson GM, Bazzaz FA (1998) Regenerating temperate forest mesocosms in elevated $\mathrm{CO}_{2}$ : belowground growth and nitrogen cycling. Oecolegia 113:115-125

Bligh EC, Dyer WJ (1959) A rapid method of total lipid extraction and purification. Can J Biochem Physiol 37:911-917

Boschker HTS, Nold SC, Wellsbury P, Bos D, De Graaf WD, Pel R, Parkes RJ, Cappenberg TE (1998) Direct linking of microbial populations to specific biogeochemical processes by ${ }^{13}$ C-labeling of biomarkers. Nature 392:801-805

Broadmeadow MSJ, Jackson SB (2000) Growth responses of Quercus petraea, Fraxinus excelsior and Pinus sylvestris to elevated carbon dioxide, ozone and water supply. New Phytol 146:437-451

Bruce KD, Jones TH, Bezemer TM, Thompson LJ, Ritchie DA (2000) The effect of elevated atmospheric carbon dioxide levels on soil bacterial communities. Global Change Biol 6:427-434

Canadell JG, Pitelka LF, Ingram JSI (1996) The effects of elevated $\mathrm{CO}_{2}$ on plant-soil carbon belowground: a synthesis. Plant Soil 187:391-400

Carreiro MM, Howe K, Parkhurst DF, Pouyat RV (1999) Variation in quality and decomposability of red oak leaf litter along an urban-rural gradient. Biol Fertil Soils 33:258-268

Carreiro MM, Sinsabaugh RL, Repert DA, Parkhurst DF (2000) Microbial enzyme shifts explain litter decay responses to simulated nitrogen deposition. Ecology 81:2359-2365

Curtis PS (1996) A meta-analysis of leaf gas exchange and nitrogen in trees grown under elevated carbon dioxide. Plant Cell Environ 19:127-137

DeLucia EH, Thomas RB (2000) Photosynthetic responses to $\mathrm{CO}_{2}$ enrichment of four hardwood species in a forest understory. Oecologia 122:11-19

DeLucia EH, Hamilton JG, Naidu SL, Thomas RB, Andrews JA, Finzi A, Lavine M, Matamala R, Mohan JE, Hendrey GR, Schlesinger WH (1999) Net primary production of a forest ecosystem with experimental $\mathrm{CO}_{2}$ enrichment. Science 289: 1177-1179

Dhillion SS, Roy J, Abrams M (1996) Assessing the impact of elevated $\mathrm{CO}_{2}$ on soil microbial activity in a Mediterranean model ecosystem. Plant Soil 187:333-342

Dickson RE, Lewin KF, Isebrands JG, Coleman MD, Heilman WE, Riemenschneider DE, Sober J, Host GE, Zak DR, Hendrey GR, Pregitzer KS, Karnosky DF (2000) Forest atmosphere carbon transfer and storage (FACTS-II) The Aspen free-air $\mathrm{CO}_{2}$ and $\mathrm{O}_{3}$ enrichment (FACE) project: an overview. USDA Forest Service, St. Paul, Minn. pp 14-25

Edwards NT, Norby RJ (1998) Below-ground respiratory responses of sugar maple and red maple saplings to atmospheric $\mathrm{CO}_{2}$ enrichment and elevated air temperature. Plant Soil 206:85-97

Federle TW, Dobbins DC, Thortonmanning JR, Jones DD (1986) Microbial biomass, activity, and community structure in subsurface soils. Ground Water 24:365-374

Findlay S, Carreiro MM, Krischik V, Jones CG (1996) Effects of damage to living plants on leaf litter quality. Ecol Appl 6: $269-275$

Finlayson-Pitts BJ, Pitts JN Jr (1997) Tropospheric air pollution: ozone, airborne toxics, polycyclic aromatic hydrocarbons, and particulates. Science 276:1045-1051

Frostegård A, Bååth E (1996) The use of phospholipid fatty acid analysis to estimate bacterial and fungal biomass in soil. Biol Fertil Soils 22:59-65

Gehron JJ, White DC (1983) Sensitive assay of phospholipid glycerol in environmental samples. J Microbiol Methods 1:23-32

Graystone SJ, Griffith GS, Mawdsley JL, Campbell CD, Bardgett RD (2000) Accounting for variability in soil microbial communities of temperate upland grassland ecosystems. Soil Biol Biochem 33:533-551

Hättenschwiler S, Körner C (2000) Tree seedling responses to in situ $\mathrm{CO}_{2}$-enrichment differ among species and depend on understory light availability. Global Change Biol 6:213-226

Hungate BA, Canadell J, Chapin FS III (1996) Plant species mediate changes in soil microbial $\mathrm{N}$ in response to elevated $\mathrm{CO}_{2}$. Ecology 77:2505-2515
Hungate BA, Holland EA, Jackson RB, Chapin FS, III, Mooney HA, Field CB (1997) The fate of carbon in grasslands under carbon dioxide enrichment. Nature 388:576-579

Hungate BA, Dijkstra P, Johnson DW, Hinkle CR, Drake BG (1999) Elevated $\mathrm{CO}_{2}$ increases nitrogen fixation and decreases soil nitrogen mineralization in Florida scrub oak. Global Change Biol 5:781-789

Hungate BA, Jaeger CH III, Gamara G, Chapin FS III, Field CB (2000) Soil microbiota in two annual grasslands: responses to elevated atmospheric $\mathrm{CO}_{2}$. Oecologia 124:589-598

Islam KR, Mulchi CL, Ali JA (2000) Interactions of tropospheric $\mathrm{CO}_{2}$ and $\mathrm{O}_{3}$ enrichments and moisture variations on microbial biomass and respiration in soil. Global Change Biol 6: $255-265$

Jones TH, Thompson LJ, Lawton JH, Bezemer TM, Bardgett RD, Blackburn TM, Bruce KD, Cannon PF, Hall GS, Hartley SE, Howson G, Jones CG, Kampichler C, Kandeler E, Ritchie DA (1998) Impacts of rising atmospheric carbon dioxide on model terrestrial ecosystems. Science 280:441-443

Karnosky DF, Gagnon ZE, Dickson RE, Coleman MD, Lee EH, Isebrands JG (1996) Changes in growth, leaf abscission, and biomass associated with seasonal tropospheric ozone exposures of Populus tremuloides clones and seedlings. Can J For Res 26:23-37

King JS, Pregitzer KS, Zak DR, Sober J, Isebrands JG, Dickson RE, Hendrey GR, Karnosky DF (2001) Fine root biomass and fluxes of soil carbon in young stands of paper birch and trembling aspen as affected by elevated atmospheric $\mathrm{CO}_{2}$ and tropospheric $\mathrm{O}_{3}$. Oecologia 128:237-250

Larson J, Zak DR, Holmes WE (in press) Extracellular enzyme activity and metabolism of root-derived substrates beneath temperate trees growing under elevated $\mathrm{CO}_{2}$ and $\mathrm{O}_{3}$. Soil Sci Soc Am J

Matamala R, Schlesinger WH (2000) Effects of elevated atmospheric $\mathrm{CO}_{2}$ on fine root production and activity in an intact temperate forest ecosystem. Global Change Biol 6(8):967-979

Medlyn BE, Barton CVM, Broadmeadow MSJ, Ceulemans R, De Angelis P, Forstreuter M, Freeman M, Jackson SB, Kellomaki S, Laitat E, Rey A, Roberntz P, Sigurdsson BD, Strassemeyer J, Wang K, Curtis PS, Jarvis PG (2001) Stomatal conductance of forest species after long-term exposure to elevated $\mathrm{CO}_{2}$ concentration: a synthesis. New Phytol 149:247-264

Norby RJ (1994) Issues and perspectives for investigating root responses to elevated atmospheric $\mathrm{CO}_{2}$. Plant Soil 165:9-20

Pregitzer KS, Zak DR, Curtis PS, Kubiske ME, Teeri JA, Vogel CS (1995) Atmospheric $\mathrm{CO}_{2}$, soil nitrogen and turnover of fine roots. New Phytol 129:579-585

Pregitzer KS, Zak DR, Maziasz J, DeForest J, Curtis PS, Lussenhop J (2000) Interactive effects of atmospheric $\mathrm{CO}_{2}$ and soil-N availability on fine roots of Populus tremuloides. Ecol Appl $10: 18-33$

Pye JM (1988) Impact of ozone on the growth and yield of trees: a review. J Environ Qual 17:347-360

Ratledge S, Wilkinson SG (1988) Microbial lipids. Academic Press, San Diego, Calif.

Rice CW, Garcia FO, Hampton CO, Owensby CE (1994) Soil microbial response in tallgrass prairie to elevated $\mathrm{CO}_{2}$. Plant Soil 165:67-74

Rillig MC, Scow KM, Klironomos JN, Allen MF (1997) Microbial carbon-substrate utilization in the rhizosphere of Gutierrezia sarothrae grown in elevated atmospheric carbon dioxide. Soil Biol Biochem 29:1387-1394

Rillig MC, Hernandez GY, Newton PCD (2000) Arbuscular mycorrhizae respond to elevated atmospheric $\mathrm{CO}_{2}$ after longterm exposure: evidence from a $\mathrm{CO}_{2}$ spring in New Zealand supports the resource balance model. Ecol Lett 3:475-478

Ringelberg DB, Stair JO, Almeida J, Norby RJ, O'Neill EG, White DC (1997) Consequences of rising atmospheric carbon dioxide levels for the belowground microbiota associated with white oak. J Environ Qual 26:495-503

Schlesinger WH (1997) Biogeochemistry: an analysis of global change. Academic Press, San Diego, Calif. 
Sinsabaugh RL (1994) Enzymatic analysis of microbial pattern and process. Biol Fertil Soils 17:69-74

Veen JA van, Liljeroth E, Lekkerkerk LJA, Geijn SC van de (1991) Carbon fluxes in plant-soil systems at elevated atmospheric $\mathrm{CO}_{2}$ levels. Ecol Appl 1:175-181

White DC, Davis WM, Nickels JS, King JS, Bobbie RJ (1979) Determination of the sedimentary microbial biomass by extractable lipid phosphate. Oecologia 40:51-62

Williams MA, Rice CW, Owensby CE (2000) Carbon dynamics and microbial activity in tallgrass prairie exposed to elevated $\mathrm{CO}_{2}$ for 8 years. Plant Soil 227:127-137

Yoshida LC, Gamon JA, Andersen, CP (2001) Differences in above- and below-ground responses to ozone between two populations of a perennial grass. Plant Soil 233:203-211
Zak DR, Pregitzer KS, Curtis PS, Teeri JA, Fogel R, Randlett DL (1993) Elevated atmospheric carbon dioxide and feedback between carbon and nitrogen cycles. Plant Soil 151: $105-117$

Zak DR, Ringelberg DB, Pregitzer KS, Randlett DL, White DC, Curtis PS (1996) Soil microbial communities beneath Populus grandidentata crown under elevated atmospheric $\mathrm{CO}_{2}$. Ecol Appl 6:257-262

Zak DR, Pregitzer KS, King JS, Holmes WE (2000) Elevated atmospheric $\mathrm{CO}_{2}$, fine roots and the response of soil microorganisms: a review and hypothesis. New Phytol 147: $201-222$ 